\title{
Effects of the Adoption of Integrated Reporting on the Information Needs of Capital Providers: Evidence from Nigeria
}

\author{
Abel Aigbodion Asein \\ PhD Accounting Student \\ Babcock University, Ilisan-Remo, Ogun State, Nigeria \\ Dr. Festus Folajimi Adegbie \\ Head, Department of Accounting \\ Babcock University, Ilisan-Remo, Ogun State, Nigeria \\ \& \\ Ishola Rufus Akintoye \\ Professor of Accounting \\ Babcock University, Ilisan-Remo, Ogun State, Nigeria
}

\begin{abstract}
Corporate entities use variants of capital to create value. Studies have shown that the resultant financial statements satisfy only the information needs of financial capital providers, thereby creating the misleading impression that organisations can operate without other capitals. This lapse impairs the decision usefulness of financial statements and creates information expectation gap as stakeholders now desire financial and non-financial information to make investment decisions. This study sought to determine whether integrated reporting practice will satisfy the information needs of stakeholders of Nigerian listed companies. This study used survey research design which involved the administration of questionnaire to 400 respondents selected from a population of 82,353 professional accountants in Nigeria in 2018. The sampling techniques were purposive and convenience. The questionnaire's construct validity, content reliability and internal consistency tests were done with Partial Least Square-Structural Equation modelling and it produced Average Variance Extracted (AVE)>0.5 and Composite Reliability (CR)>0.7; and Cronbach Alpha values ranging from 0.716 to 0.951 indicating reliability and validity of the questionnaire. Out of the 400 copies of questionnaire administered, 378 were retrieved indicating a response rate of $95 \%$. The data obtained were analysed using descriptive and inferential statistics. From the findings, the study determined the nature of the relationships which exist between the 8 content elements and each of the reclassified 4 variants of capital. It also revealed the degree of influence which a content element (the independent variable) can have on a variant of capital (dependent variable). These findings were validated by the computed results of the various t-tests, adjusted $R^{2}$ and F-statistics at the significance level of $p<0.05$. Using the Stakeholder theory, this study determined that corporate reports should contain information needs of all capital providers. Conclusively, the study established that integrated reporting practices will satisfy the information needs of all capital providers and recommended the mandatory adoption of integrated reporting framework by the Financial Reporting Council of Nigeria as desired by stakeholders of Nigeria quoted companies.
\end{abstract}

Keywords: Integrated reporting, Interconnectivity, Resource dependence, Stakeholders' information needs, Variants of capital.

\subsection{Introduction}

The environment of business is rapidly changing and so are the sources of financing, strategies and models for value creation. In response to these dynamics, corporate reports cannot afford to be tardy if they are desirous of capturing the changing needs of stakeholders and the information required by diverse capital providers to make optimal resource allocation decisions. The experience of the 2007/2008 global financial crisis points to the fact that financial statement is an inadequate, if not poor, measure of the worth of an entity and its ability to create wealth (Adhariani \& de Villiers, 2018; Kilic \& Kuzey, 2018). Assessing and measuring the health of a company solely with financial indicators is now ill-advised (Demirol \& Erol, 2016). The inability of subsisting corporate reporting practices to meet the needs of stakeholders has diminished their value relevance and decision usefulness. Thus, to sustain trust, entities need to revisit the way they engage with and communicate information to capital providers (Ghosh, 2019) and by extension, how they measure corporate performance and worth. 
Lately, there has been an increasing trend towards the inclusion of non-financial information in corporate reports (Roman, Mocanu \& Hoinaru, 2019) in response to stakeholders' demand for more accountability and transparency. Stakeholders, as providers of capital, now require narrative non-financial information on organisations' business models, governance, strategy, risks and opportunities as well as how value is created in the short, medium and long term \{International Integrated Reporting Council (IIRC), 2013; Tweedie, Nielsen \& Martinov-Bennie, 2018\}. They also desire holistic view about the firm's future capacity to create value.

Integrated reporting has emerged as the reporting framework that can satisfy this need because it contains both financial and non-financial information required by capital providers. The traction on integrated report lies in the value it brings to organization through integrated thinking as this "marks a change in the way in which companies envisage, design and run their business (Busco, Frigo, Quattrone, \& Riccaboni, 2014, p.24)". Its message of interconnectivity of information and interdependence of capitals in the process of value creation, points to the value relevance of financial and non-financial information even as they manage risks and leverage opportunities. According to Alucha, Hussain and Roszkowska-Mendes (2019, p.3), integrated reporting helps "firms provide an overview of the sustainability and economic performance at the same place that bridges the information gap between non-financial and financial information."

From the perspective of communication with stakeholders, the integrated reporting concept has the great advantage not only of providing the desired connectivity of information but also, of integrating financial and non-financial information into a single concise document. This will increase the effectiveness of research and analysis of data by stakeholders who until now, had to search through numerous corporate publications to obtain decision useful information (Eccles \& Krzus, 2010; Matuszyk \& Rymkieicz, 2018). Roman, Mocanu and Hoinaru (2019) shared this perspective when they observed that integrated reporting will help to promote a more cohesive and efficient approach to corporate reporting. This, according to them, will improve the quality of information available to capital providers.

Besides the fact that integrated report creates a strategic tool to determine the degree of association between financial and non-financial performances (Ioana \&Tiron-Tudor, 2014), it smoothens the relationship between an entity and the host community thereby legitimizing its existence and enhancing corporate reputation (Ioana \&Tiron-Tudor, 2014; Orshi, Dandago \& Isa, 2019). With integrated reporting, entities are best placed to identify opportunities and risks associated with their businesses (IIRC, 2013) and this will facilitate optimal allocation of corporate resources (Oliveira, Rodrigues \& Craig, 2011) with positive impact on cost of capital (Frias-Aceituno, Rodriguez-Ariza, \& Garcia, 2014).

However, unlike IFRS-based general purpose financial statements (GPFS), integrated reporting is not mandatory in Nigeria and in most jurisdictions despite its established benefits. As a result, material non-financial information are not included in the mandatory corporate reports making them deficient and inappropriate basis for decision making. Despite the fact that entities can voluntarily adopt integrated reporting which will enable them include non-financial information in their corporate reports, there is no evidence of any such voluntary compliance in Nigeria. What exists, especially in the oil and gas sector, are adhoc, short term and disclosures that are unrelated to the core activities of the entities (Ayoola \& Olasanmi, 2013).The non-inclusion of non-financial information in GPFS has made it inadequate, incomplete and unreliable basis for decision making by stakeholders of listed entities in Nigeria. Since stakeholders now require both financial and non-financial information to take optimal resource allocation decision (Hurghis, 2017; IIRC, 2017; Ioana \&Tiron-Tudor, 2014), there is need to ascertain if integrated reporting practices will satisfy the needs of these capital providers. This is the objective of this study.

The remaining part of this paper is segmented into six parts. Section 2 contains the literature review while section three presents the methodology. Section four contains data presentation and analysis while section five contains results of the tested hypotheses. The last section presents the findings, conclusions and recommendations.

\subsection{Literature Review}

The focus of the IASB (2018) Conceptual Framework and standards, is the preparation of high quality GPFS, which will enhance confidence in and drive investment activities in capital markets around the globe. Although such standards conform to laws and legislation in Nigeria and other jurisdictions, they do not satisfy the diverse, dynamic and increasingly sophisticated information needs of stakeholders (Naynar, Ram \& Maroun, 2018). Whereas, in the past, stakeholders were primarily interested in financial information, attention is growing for other non-financial organizational aspects such as environmental consequences, social and governance structure (Ghosh, 2019; Hertgers, 2016). The growing phenomenon of socially responsible investment, makes the provision of narrative non-financial information on negative externalities of business activities also imperative (Moolman, Oberholzer \& Steyn, 2016). 
The absence of both a framework and standard for the presentation of non-financial information makes it difficult for such stakeholders to compare the performance of different companies (Eccles \& Saltzman, 2011), thereby reducing the materiality, value relevance and reliability of such information (Gianfelici, Casadei \& Cembali, 2016). Furthermore, GPFS no longer reflect the actual worth of the organization neither do they provide adequate comfort to existing and prospective investors as they fail to describe all risks associated with business including social and environmental risks (Cotter, Najah \& Wang, 2011; Eccles \& Krzus, 2010; Stubbs, Higgins \& Higgins, 2016). Here lies the traction for a framework that can provide both financial and non-financial information in a report as required by stakeholders.

Although preparers of corporate reports have sought to fill the observed information gap by issuing some non-financial reports in the form of sustainability report, corporate social responsibility report and strategy report (in UK), these are largely stand-alone and voluminous reports with no links to other reports and reference to the interdependence between the variants of capital and interconnectivity of information in various reports (Robertson \& Samy, 2015). Besides, literature affirms that what gets included in these reports depends on stakeholders' activism and sophistication, the source of power and legitimacy of the stakeholders, ownership structure of the entity and board composition (Adegbie, Akintoye \& Olusanjo, 2019; Gianfelici, 2016; Matuszyk \& Rymkiewicz, 2018; Naylar, Ram \& Maroun, 2018; Orshi, Dandago \& Isa, 2019). The implication is that the information needs of stakeholders are not satisfied prompting the call for mandatory adoption of integrated reporting framework (Haji Anifowose, 2016; Sukhari \& de Villiers, 2018). Evidence from South Africa, the first country to introduce mandatory integrated reporting shows that the legislative requirement "has resulted in an increase in the extent of disclosure of human, social and relational, natural and intellectual capital information of the listed companies (Setia, Abhayawansa, Joshi \& Huynh, 2015, p.397)”. Thus, to satisfy the information needs of stakeholders of listed entities in Nigeria, the corporate reporting framework needs to be changed to mandatorily incorporate both financial and non-financial information.

\subsection{Theoretical Consideration}

This study was carried out to examine how the adoption of integrated reporting framework will satisfy the information needs of stakeholders of Nigerian quoted companies. For studies in Financial reporting and information needs of users, many theories are relevant but the Stakeholder's theory is considered not only comprehensive but most appropriate.

\subsection{Stakeholder Theory}

First espoused by Schwab (1971), the Stakeholder theory is based on the assumptions that business entities operate and have their being in a given environment. Therefore, their activities will affect or are affected by third parties who might be individuals, group of persons, providers of other variants of capital, the communities, customers, suppliers, trade creditors, employees, regulators and the government. The theory argues that a modern business entity must serve not only the interests of shareholders but also, of all stakeholders (providers of all variants of capital) if it is desirous of achieving long term growth and prosperity. Thus, corporate entities, in their own interests, have a duty to promote the well-being of their host communities and people. However, Friedman(1962) was not persuaded by this view. According to Friedman (1962, p.133), “...there is one and only social responsibility of business-to use its resources and engage in activities designed to increase its profits so long as it stays within the rules of the game, which is to say, engages in open and free competition without deception and fraud." In other words, persons who act in fiduciary positions are morally and legally obliged to faithfully pursue this profit objective in the interest of their principals who are the shareholders and equity owners and report same in their stewardship reports.

However, in the view of the leading advocates of stakeholder's theory (Freeman \& Evan, 1990; Freeman, 1994), there exists a social contract between an entity and the society where it has its being. It is therefore obligated to fulfil its part by taking care of the environment through corporate social responsibility initiatives and reporting thereon for the information and benefit of all. Donaldson and Preston (1995), Enderle (2004) and Freeman et al., (2010) share this view when they noted that the shareholder theory was too simplistic by assuming that the main purpose of business is to maximize profit. They argued that values are created by corporate entities based on relationships and hence, people, environment and other third parties have a stake in the entity's survival. How to satisfy the needs of these interest groups is the philosophy of stakeholder theory (Farneti, Casonato, Montecalvo \& de Villiers, 2019; Gray, Kouhy \& Lavers, 1995). Serving the interests of stakeholders will involve providing full financial and non-financial information which they require to make resource allocation decisions. The reporting framework which approximates this ideal corporate report is the integrated reporting framework. Its adoption may lead to the satisfaction of the information needs of other capital providers. To ascertain the efficacy of this, the following hypotheses were tested.

\subsection{Statement of Hypotheses}

The following hypotheses were tested in this study to elicit information on the variants of capital employed in the Nigerian corporate environment and the information needs of providers of such capital. 
- $\mathrm{H}_{01}$ : integrated report will not significantly satisfy the information needs of providers of financial and manufactured capital.

- $\mathrm{H}_{02}$ : integrated report will not significantly satisfy the information needs of providers of human and intellectual capital.

- $\mathrm{H}_{03}$ : integrated report will not significantly satisfy the information needs of providers of environmental capital.

- $\mathrm{H}_{04}$ : integrated report will not significantly satisfy the information needs of providers of social and relationship capital.

- $\mathrm{H}_{05}$ :integrated report will not significantly satisfy the information needs of providers of combined capitals.

The a-priori expectation of the study was that $\mathrm{H}_{01}-\mathrm{H}_{05}=\beta>0$.

\subsection{Methodology}

This study used a survey design which involved the administration of questionnaire to 400 respondents selected from a population of 82,353 professional accountants in Nigeria as at December 31, 2018 (ICAN, 2018; ANAN, 2018) using the universal Taro Yamane formula. As members of the two accounting bodies in Nigeria, they serve as preparers, users, audit/assurance providers, advisors, reporting accountants and regulators. The questionnaire was tested for both construct validity and content reliability with Partial Least Square-Structural equation modelling which yielded Average Variance Extracted $>0.5$ and Cronbach Alpha of $>0.7$, respectively. The 2-part questionnaire had 52 closeended questions. The Likert Scale was used to rank the multiple choice responses provided. Data were analyzed using descriptive and inferential statistics at 0.05 level of significance.

\subsection{Research Model}

Let $\mathrm{Y}=$ Dependent Variable; and $\mathrm{X}=$ Independent Variable. Then, $\mathrm{Y}=\int(\mathrm{X})$

$\mathrm{Y}=\mathrm{y}_{\mathrm{i},} \mathrm{y}_{\mathrm{ii}}, \mathrm{y}_{\mathrm{iii}}, \mathrm{y}_{\mathrm{iv}}, \mathrm{y}_{\mathrm{v}}$

$\mathrm{y}_{\mathrm{i}}=\mathrm{INFMCP}=$ Information Needs of Financial and Manufactured Capital Providers

$\mathrm{y}_{\mathrm{ii}}=\mathrm{INHICP}=$ Information Needs of Human and Intellectual Capital Providers

$\mathrm{y}_{\mathrm{iii}}=\mathrm{INECP}=$ Information Needs of Environmental Capital Providers

$\mathrm{y}_{\mathrm{iv}}=\mathrm{INSRCP}=$ Information Needs of Social and Relationship Capital Providers

$\mathrm{y}_{\mathrm{v}}=\mathrm{INCCP}=$ Information Needs of Combined Capital Providers

$\mathrm{Y}=\mathrm{INFMCP}_{\mathrm{i}}+\mathrm{INHICP}_{\mathrm{i}}+\mathrm{INECP}_{\mathrm{i}}+\mathrm{INSRCP}_{\mathrm{i}}+\mathrm{INCCP}_{\mathrm{i}}$

$\mathrm{X}=\mathrm{x}_{\mathrm{i},}, \mathrm{x}_{\mathrm{ii}}, \mathrm{x}_{\mathrm{iii}}, \mathrm{X}_{\mathrm{iv}}, \mathrm{x}_{\mathrm{v}}, \mathrm{x}_{\mathrm{vi}}, \mathrm{X}_{\mathrm{vii}}, \mathrm{X}_{\mathrm{viii}}$

$\mathrm{x}_{\mathrm{i}}=$ OREER $=$ Organizational Overview and External Environment Report

$\mathrm{x}_{\mathrm{ii}}=\mathrm{GovR}=$ Governance Report

$\mathrm{x}_{\mathrm{iii}}=\mathrm{BMR}=$ Business Model Report

$\mathrm{x}_{\mathrm{iv}}=\mathrm{ROR}=$ Risks and Opportunities Report

$\mathrm{x}_{\mathrm{v}}=\mathrm{SRAR}=$ Strategy and Resource Allocation Report

$\mathrm{x}_{\mathrm{vi}}=\mathrm{PER}=$ Performance Report

$\mathrm{x}_{\mathrm{vii}}=\mathrm{OTR}=$ Outlook Report

$\mathrm{x}_{\mathrm{viii}}=\mathrm{BPPR}=$ Basis of Preparation and Presentation Report

Integrated Reporting is decomposed into the 8 content elements of the IIRC 2013 Framework. In other words, $\mathrm{X}=\mathrm{IR}=\mathrm{OREER}_{\mathrm{i}}+\mathrm{GovR}_{\mathrm{i}}+\mathrm{BMR}_{\mathrm{i}}+\mathrm{ROR}_{\mathrm{i}}+\mathrm{SRAR}_{\mathrm{i}}+\mathrm{PER}_{\mathrm{i}}+\mathrm{OTR}_{\mathrm{i}}+\mathrm{BPPR}_{\mathrm{i}}$.

\subsection{Functional Relationship}

$\mathrm{y}_{\mathrm{i}}=\mathrm{INFMCP}_{=}=\int\left(\mathrm{OREER}_{\mathrm{i}}, \mathrm{GovR}_{\mathrm{i}}, \mathrm{BMR}_{\mathrm{i}}, \mathrm{ROR}_{\mathrm{i}}, \mathrm{SRAR}_{\mathrm{i}}, \mathrm{PER}_{\mathrm{i}}, \mathrm{OTR}_{\mathrm{i}}, \mathrm{BPPR}_{\mathrm{i}}\right)$------EQ1

$\mathrm{y}_{\mathrm{ii}}=\mathrm{INHICP}=\int\left(\mathrm{OREER}_{\mathrm{i}}, \mathrm{GovR}_{\mathrm{i}}, \mathrm{BMR}_{\mathrm{i}}, \mathrm{ROR}_{\mathrm{i}}, \mathrm{SRAR}_{\mathrm{i}}, \mathrm{PER}_{\mathrm{i}}, \mathrm{OTR}_{\mathrm{i}}, \mathrm{BPPR}_{\mathrm{i}}\right)$------EQ2

$\mathrm{y}_{\mathrm{iii}}=\mathrm{INECP}=\int\left(\mathrm{OREER}_{\mathrm{i}}, \mathrm{GovR}_{\mathrm{i}}, \mathrm{BMR}_{\mathrm{i}}, \mathrm{ROR}_{\mathrm{i}}, \mathrm{SRAR}_{\mathrm{i}}, \mathrm{PER}_{\mathrm{i}}, \mathrm{OTR}_{\mathrm{i}}, \mathrm{BPPR}_{\mathrm{i}}\right)$--------EQ3

$\mathrm{y}_{\mathrm{iv}}=\mathrm{INSRCP}=\int\left(\mathrm{OREER}_{\mathrm{i}}, \mathrm{GovR}_{\mathrm{i}}, \mathrm{BMR}_{\mathrm{i}}, \mathrm{ROR}_{\mathrm{i}}, \mathrm{SRAR}_{\mathrm{i}}, \mathrm{PER}_{\mathrm{i}}, \mathrm{OTR}_{\mathrm{i}}, \mathrm{BPPR}_{\mathrm{i}}\right)$------EQ4

$\mathrm{y}_{\mathrm{v}}=\mathrm{INCCP}=\int\left(\mathrm{OREER}_{\mathrm{i}}, \mathrm{GovR}_{\mathrm{i}}, \mathrm{BMR}_{\mathrm{i}}, \mathrm{ROR}_{\mathrm{i}}, \mathrm{SRAR}_{\mathrm{i}}, \mathrm{PER}_{\mathrm{i}}, \mathrm{OTR}_{\mathrm{i}}, \mathrm{BPPR}_{\mathrm{i}}\right)$-------EQ5

Equation 1 will relate the Information Needs of Financial and Manufactured Capital Providers (INFMCP) to integrated report decomposed into 8 content elements of IIRC Framework. The same applies to each of the other dependent variables captured by equations $2-5$.

\subsection{Data Presentation and Analysis}

The thrusts of this section are the presentation and analysis of data. A total of 400 copies of questionnaire were administered to players in the financial reporting chain who are users, regulators, preparers, standard setters, financial 
analysts, auditors/assurance providers and 378 were returned representing $95 \%$ response rate. The demographic profile shows that 295 or $78 \%$ of the respondents were male, while the remaining 83 or $22 \%$ respondents were female. Also, the respondents comprised: preparers, 74 or 19.6\%; auditors/assurance providers, 168 or $44.4 \%$; regulators of financial reporting, 91 or $24.1 \%$; users, 39 or $10.3 \%$; and others, 6 or $1.6 \%$. These affirm that qualified personnel engaged in diverse areas of corporate reporting were picked to respond to the questionnaire. On the average, over $80 \%$ respondents agreed that the 8 content elements will satisfy the information needs of stakeholders of Nigerian quoted companies.

\subsection{Hypothesis Testing for Structural Estimates}

\subsection{Hypothesis One}

The results of this test, indicated in Table 1, show that the basis of preparation and presentation reporting, organisational overview and external environment reporting and outlook reporting, respectively, have positive and significant relationship $(B P P R=0.111, \mathrm{t}$-test $=1.963, \mathrm{p}<0.05$, OREER $=0.191$, $\mathrm{t}$-test $=2.830, \mathrm{p}<0.05, \mathrm{OTR}=0.155, \mathrm{t}-$ test $=2.162, \mathrm{p}<0.05$ ) with information needs of providers of financial and manufactured capital listed companies in Nigeria. Thus, they are the significant factors influencing changes in information needs of providers of financial and manufactured capital of quoted companies in Nigeria.

Table 1: The Effects of the Adoption of Integrated Reporting on the Information Needs of Providers of Financial and Manufactured Capital.

Panel A: Long Run Coefficients

\begin{tabular}{lcccc}
\hline \multicolumn{1}{l}{ Dependent Variable: INFMCP } & & & \\
Variables & Coefficients & Standard Error & t-stat & Prob. \\
\hline BPPR & 0.111 & 0.057 & 1.963 & 0.050 \\
BMR & 0.108 & 0.074 & 1.460 & 0.145 \\
GOVR & 0.065 & 0.073 & 0.893 & 0.372 \\
OREER & 0.191 & 0.067 & 2.830 & 0.005 \\
OTR & 0.155 & 0.072 & 2.162 & 0.031 \\
PER & 0.111 & 0.062 & 1.804 & 0.072 \\
ROR & 0.014 & 0.085 & 0.164 & 0.870 \\
SRAR & -0.016 & -0.071 & 0.224 & 0.823 \\
Panel B: Diagnostic Test & & & Stat & Prob \\
Adjusted R-Square & & & 0.275 & \\
F-Statistics & & & 15.812 & 0.000 \\
\hline
\end{tabular}

Note: The dependent variable is the Information Needs of Financial and Manufactured Capital Providers (INFMCP). The explanatory variables are: OREER, GovR, BMR, ROR, SRAR, PER, OTR and BPPR.

Conversely, there is evidence that business model reporting, governance reporting, performance reporting, risk and opportunities reporting and strategy and resource allocation reporting, respectively, do not have significant relationship with information needs of providers of financial and manufactured capital of quoted companies in Nigeria $(\mathrm{BMR}=$ $0.108, \mathrm{t}$-test $=1.460, \mathrm{p}>0.05, \mathrm{GOVR}=0.065$, $\mathrm{t}$-test $=0.893, \mathrm{p}>0.05, \mathrm{PER}=0.111$, $\mathrm{t}$-test $=1.804, \mathrm{p}>0.05, \mathrm{ROR}=0.014$, $\mathrm{t}$-test $=0.164, \mathrm{p}>0.05$ and SRAR $=-0.016$, $\mathrm{t}$-test $=0.224, \mathrm{p}>0.05)$. Therefore, they are not significant factors influencing changes in information needs of providers of financial and manufactured capital of quoted companies in Nigeria.

From the study, the Adjusted $\mathrm{R}^{2}$ explained about 28 per cent changes by these content elements in information needs of providers of financial and manufactured capital of quoted companies in Nigeria, while the remaining 72 per cent were explained by other factors not captured in the model. Its F-Statistic of 15.815 was statistically significant with $\mathrm{p}<0.05$ indicating overall that, based on the statistical significance of the model, the proposition by the null hypothesis that the adoption of integrated report will not satisfy the information needs of providers of financial and manufactured capital was rejected. Thus, the alternative hypothesis that the adoption of integrated report will satisfy the information needs of providers of financial and manufactured capital was accepted.

\subsection{Hypothesis Two}

The results of this test of hypothesis, as contained in Table 2, show that business model reporting, outlook reporting, performance reporting, and strategy and resource allocation reporting, respectively, have significant relationship $(\mathrm{BMR}=0.206, \mathrm{t}$-test $=2.628, \mathrm{p}<0.05 ;$ OTR $=0.291, \mathrm{t}$-test $=4.491, \mathrm{p}<0.05 ; \mathrm{PER}=-0.180, \mathrm{t}$-test $=2.714, \mathrm{p}<0.05$ and 
SRAR $=0.250, \mathrm{t}$-test $=3.205, \mathrm{p}<0.05)$ with information needs of providers of human and intellectual capital of listed companies in Nigeria. This implies that business model reporting, outlook reporting, performance reporting, and strategy and resource allocation reporting are significant factors influencing changes in information needs of providers of human and intellectual capital of quoted companies in Nigeria.

However, basis of preparation and presentation reporting, governance reporting, organisational overview and external environment reporting, and risk and opportunities reporting would not have significant relationship (BPPR=0.019, ttest=0.325, $\mathrm{p}>0.745 ;$ GovR $=-0.042, \mathrm{t}$-test $=0.604, \mathrm{p}>0.05 ;$ OREER=0.042, $\mathrm{t}$-test=4.491, p >0.492; ROR=0.018, ttest $=0.225, \mathrm{p}>0.822$ ), respectively, with the information needs of providers of human and intellectual capital of Nigerian listed companies. Also, governance reporting and performance reporting have negative or inverse relationship with and are not significant factors influencing changes in information needs of providers of human and intellectual capital of quoted companies in Nigeria.

Table 2: The Effects of the Adoption of Integrated Reporting on the Information Needs of Providers of Human and Intellectual Capital.

Panel A: Long Run Coefficients

\begin{tabular}{|c|c|c|c|c|}
\hline \multicolumn{5}{|c|}{ Dependent Variable: INHICP } \\
\hline Variables & Coefficients & Standard Error & t-stat & Prob. \\
\hline BPPR & 0.019 & 0.058 & 0.325 & 0.745 \\
\hline BMR & 0.206 & 0.078 & 2.628 & 0.009 \\
\hline GOVR & -0.042 & -0.070 & 0.604 & 0.546 \\
\hline OREER & 0.042 & 0.061 & 0.688 & 0.492 \\
\hline OTR & 0.291 & 0.065 & 4.491 & 0.000 \\
\hline PER & -0.180 & -0.066 & 2.714 & 0.007 \\
\hline ROR & 0.018 & 0.080 & 0.225 & 0.822 \\
\hline SRAR & 0.250 & 0.078 & 3.205 & 0.001 \\
\hline \multicolumn{3}{|c|}{ Panel B: Diagnostic Test } & Stat & Prob \\
\hline \multicolumn{3}{|c|}{ Adjusted R-Square } & 0.343 & \\
\hline \multicolumn{3}{|c|}{ F-Statistics } & 21.495 & 0.000 \\
\hline
\end{tabular}

From the study, the Adjusted $\mathrm{R}^{2}$ explained about 34 per cent changes in information needs of providers of human and intellectual capital of quoted companies in Nigeria, while the remaining 66 per cent were explained by other factors not captured in the model. Its F-Statistic of 21.495 was statistically significant with $p<0.05$ indicating overall that, based on the statistical significance of the model, the proposition by the null hypothesis that the adoption of integrated report will not satisfy the information needs of providers of human and intellectual capital was not accepted. Thus, the alternative hypothesis that the adoption of integrated report will satisfy the information needs of providers of human and intellectual capital was accepted. 


\subsection{Hypothesis Three}

Table 3: The Effects of the Adoption of Integrated Reporting on the Information Needs of Providers of Environmental Capital.

Panel A: Long Run Coefficients

\begin{tabular}{lcccc}
\hline \multicolumn{1}{l}{ Dependent Variable: INECP } & \multicolumn{3}{l}{} \\
\hline Variables & Coefficients & Standard Error & t-stat & Prob. \\
\hline BPPR & -0.084 & -0.054 & 1.562 & 0.119 \\
BMR & 0.185 & 0.062 & 2.981 & 0.003 \\
GOVR & -0.079 & -0.063 & 1.254 & 0.210 \\
OREER & -0.015 & -0.059 & 0.254 & 0.800 \\
OTR & 0.340 & 0.061 & 5.563 & 0.000 \\
PER & -0.123 & -0.055 & 2.238 & 0.026 \\
ROR & 0.067 & 0.063 & 1.058 & 0.291 \\
SRAR & 0.271 & 0.064 & 4.217 & 0.000 \\
Panel B: Diagnostic Test & & & Stat & Prob \\
Adjusted R-Square & & & 0.398 & \\
F-Statistics & & & 27.015 & 0.000 \\
\hline
\end{tabular}

Note: The dependent variable is the Information Needs of Environmental Capital Providers (INECP). The explanatory variables are: OREER, GovR, BMR, ROR, SRAR, PER, OTR and BPPR.

From Table 3, the results obtained from this test show that business model reporting, outlook reporting, and strategy and resource allocation reporting, respectively, have positive and significant relationship $(B M R=0.185, t$-test $=2.981, p$ $<0.05$, OTR $=0.340$, t-test $=5.563, \mathrm{p}<0.05 ; \mathrm{SRAR}=0.271, \mathrm{t}$-test $=4.217, \mathrm{p}<0.05)$ with information needs of providers of environmental capital of listed companies in Nigeria. This implies that these elements are significant factors influencing changes in information needs of providers of environmental capital of quoted companies in Nigeria. Although it has a negative coefficient, performance reporting has a significant relationship with information needs of environmental capital providers. However, basis of preparation and presentation reporting, governance reporting, organizational overview and external environment reporting and performance reporting have negative relationship with and do not have significant influence on factors affecting changes in the information needs of providers of environmental capital of listed companies in Nigeria.

From the study, the Adjusted $\mathrm{R}^{2}$ explained about 40 per cent changes in information needs of providers of environmental capital of quoted companies in Nigeria, while the remaining 60 per cent were explained by other factors not captured in the model. Its F-Statistic of 27.015 was statistically significant with $p<0.05$ indicating overall that, based on the statistical significance of the model, the proposition by the null hypothesis that the adoption of integrated report will not satisfy the information needs of providers of environmental capital was not accepted. Thus, the alternative hypothesis that the adoption of integrated report will satisfy the information needs of providers of environmental capital was accepted.

\subsection{Hypothesis Four}

This hypothesis sought to assess the effect of integrated reporting practices on the information needs of providers of social and relationship capital of quoted companies in Nigeria. As indicated in Table 4, the results obtained from the analysis of data show that the business model reporting, governance reporting, outlook reporting, and strategy and resource allocation reporting, respectively, have significant relationship $(B M R=0.212$, $t$-test $=3.694, p<0.05, G O V R=$ $-0.140, \mathrm{t}$-test $=2.013, \mathrm{p}<0.05, \mathrm{OTR}=0.276$, t-test $=4.635, \mathrm{p}<0.05, \mathrm{PER}=-0.243$, t-test $=3.926, \mathrm{p}<0.05$ and $\mathrm{SRAR}=$ 0.312 , t-test $=5.341, \mathrm{p}<0.05$ ) with information needs of providers of social and relationship capital listed companies in Nigeria. This implies that these content elements were significant factors influencing changes in information needs of providers of social and relationship capital of quoted companies in Nigeria. 
Table 4: The Effects of the Adoption of Integrated Reporting on the Information Needs of Social and Relationship Capital Providers.

Panel A: Long Run Coefficients

Dependent Variable: INSRCP

\begin{tabular}{lcccc}
\hline Variables & Coefficients & Standard Error & t-stat & Prob. \\
\hline BPPR & -0.047 & -0.056 & 0.832 & 0.406 \\
BMR & 0.212 & 0.057 & 3.694 & 0.000 \\
GOVR & -0.140 & -0.070 & 2.013 & 0.045 \\
OREER & -0.002 & -0.047 & 0.043 & 0.966 \\
OTR & 0.276 & 0.060 & 4.635 & 0.000 \\
PER & -0.243 & -0.062 & 3.926 & 0.000 \\
ROR & 0.107 & 0.060 & 1.781 & 0.076 \\
SRAR & 0.312 & 0.058 & 5.341 & 0.000 \\
Panel B: Diagnostic Test & & & Stat & Prob \\
Adjusted R-Square & & & 0.414 & \\
F-Statistics & & & 28.850 & 0.000 \\
\hline
\end{tabular}

Note: The dependent variable is the Information Needs of Social and Relationship Capital Providers (INSRCP). The explanatory variables are: OREER, GovR, BMR, ROR, SRAR, PER, OTR and BPPR.

However, basis of preparation and presentation reporting, organization overview and external environment reporting and performance reporting, respectively, have negative relationship $(\mathrm{BPPR}=-0.047, \mathrm{t}$-test $=0.832, \mathrm{p}>0.05, \mathrm{OREER}=-$ 0.002 , t-test $=0.043, \mathrm{p}>0.05$ ) with information needs of providers of social and relationship capital listed companies in Nigeria. The implication of this is that basis of preparation and presentation reporting, organizational overview and external environment reporting are not significant factors influencing changes in information needs of providers of social and relationship capital of quoted companies in Nigeria. Although risk and opportunities reporting has positive coefficient $(\mathrm{ROR}=0.107$, $\mathrm{t}$-test $=1.781, \mathrm{p}>0.05)$, it does not have a significant relationship with the information needs of social and relationship capital providers. From the study, the Adjusted $\mathrm{R}^{2}$ explained about 41 percent changes in information needs of providers of social and relationship capital quoted companies in Nigeria, while the remaining 59 per cent were explained by other factors not captured in the model. Its F-Statistic of 28.850 was statistically significant with $p<0.05$ indicating overall that, based on the statistical significance of the model, the proposition by the null hypothesis that the adoption of integrated report will not satisfy the information needs of providers of social and relationship capital was not accepted. Thus, the alternative hypothesis that the adoption of integrated report will satisfy the information needs of providers of social and relationship capital was accepted.

\subsection{Hypothesis Five}

The focus of this hypothesis was to assess the effect of integrated reporting practices on the information needs of providers of combined capitals of quoted companies in Nigeria. From Table 5, the results show that the business model reporting, outlook reporting, performance reporting, and strategy and resource allocation reporting, respectively, have significant relationship $(\mathrm{BMR}=0.223$, $\mathrm{t}$-test $=3.907, \mathrm{p}<0.05 ; \mathrm{OTR}=0.333$, t-test $=5.424, \mathrm{p}<0.05 ; \mathrm{PER}=-0.160$, $\mathrm{t}$-test $=2.820, \mathrm{p}<0.05$; and SRAR $=0.273$, t-test $=4.858, \mathrm{p}<0.05$ ) with information needs of providers of combined capitals of listed companies in Nigeria. This implies that these content elements are significant factors influencing changes in information needs of providers of combined capital of quoted companies in Nigeria. 
Table 5: The Effects of the Adoption of Integrated Reporting on the Information Needs of Providers of Combined Capital.

Panel A: Long Run Coefficients

\begin{tabular}{lcccc}
\hline \multicolumn{1}{l}{ Dependent Variable: INCCP } & \multicolumn{3}{l}{} \\
\hline Variables & Coefficients & Standard Error & t-stat & Prob. \\
\hline BPPR & -0.008 & -0.050 & 0.161 & 0.872 \\
BMR & 0.223 & 0.057 & 3.907 & 0.000 \\
GOVR & -0.072 & -0.061 & 1.178 & 0.239 \\
OREER & 0.048 & 0.057 & 0.837 & 0.403 \\
OTR & 0.333 & 0.061 & 5.424 & 0.000 \\
PER & -0.160 & -0.057 & 2.820 & 0.005 \\
ROR & 0.070 & 0.058 & 1.203 & 0.230 \\
SRAR & 0.273 & 0.056 & 4.858 & 0.000 \\
Panel B: Diagnostic Test & & & Stat & Prob \\
Adjusted R-Square & & & 0.467 & \\
F-Statistics & & & 35.451 & 0.000 \\
\hline
\end{tabular}

Note: The dependent variable is the Information Needs of Combined Providers (INCCP). The explanatory variables are: OREER, GovR, BMR, ROR, SRAR, PER, OTR and BPPR.

However, basis of preparation and presentation reporting and governance reporting, respectively, have negative and insignificant relationship $(\mathrm{BPPR}=-0.008, \mathrm{t}$-test $=0.161, \mathrm{p}>0.05, \mathrm{GOVR}=-0.072, \mathrm{t}$-test $=1.178, \mathrm{p}>0.05)$ with information needs of providers of combined capitals of listed companies in Nigeria. Also, organizational overview and external environment reporting and risk and opportunity reporting, respectively, have positive but insignificant relationship (OREER $=0.048$, $\mathrm{t}$-test $=0.837, \mathrm{p}>0.05$ and $\mathrm{ROR}=0.070$, $\mathrm{t}$-test $=1.203, \mathrm{p}>0.05)$ with information needs of combined capital providers. Accordingly, these content elements are not significant factors influencing changes in information needs of providers of combined capitals of quoted companies in Nigeria.

From the study, the Adjusted $\mathrm{R}^{2}$ explained about 47 per cent changes in information needs of providers of combined capitals of quoted companies in Nigeria, while the remaining 53 per cent were explained by other factors not captured in the model. Its F-Statistic of 35.451 was statistically significant with $p<0.05$ indicating overall that, based on the statistical significance of the model, the proposition by the null hypothesis that the adoption of integrated report will not satisfy the information needs of providers of combined capital was not accepted. Thus, the alternative hypothesis that the adoption of integrated report will satisfy the information needs of providers of combined capital was accepted.

\subsection{Findings, Conclusions and Recommendations}

\subsection{Findings}

This study set out to determine whether integrated reporting decomposed into the 8 Content Elements by the 2013 IIRC Framework would satisfy the information needs of stakeholders of Nigerian quoted companies. As contained in Table 6 in the Appendix, the findings from the 5 hypotheses tested show that some content elements would have positive and significant relationships with some variants of capitals while some others would have positive but insignificant relationship with some variants of capital. Similarly, some content elements would have negative relationships with some capitals. The degree of influence which a content element can have on a variant of capital is shown by the value of its coefficient which may be positive or negative as indicated in the various test tables. The implications of these results are that: an entity which seeks a variant of capital now knows the content element which affects it negatively, positively or significantly as well as the magnitude of its effect. Accordingly, the entity will therefore not waste its efforts on content elements which negatively affect access to such a variant of capital. The strategic information will have positive impact on efficiency, quality of reports and optimality of corporate decisions.

\subsection{Conclusion}

Although the nature and content of the subsisting traditional financial statements are defined by law, standards and the conceptual framework, they have failed to satisfy the information needs of stakeholders of Nigerian listed entities. Many research works have advocated the adoption of integrated reporting as the ideal corporate reporting framework since it contains both financial and non-financial information desired by capital providers. 
This study therefore sought to determine whether integrated reporting will satisfy the information needs of capital providers (INFMCP, INHICP, INECP, INSRCP \& INCCP).The results from the tests of 5 hypotheses affirm that the adoption of integrated reporting will satisfy the information needs of stakeholders of listed companies in Nigeria. The alternative hypothesis was accepted in each case.

\subsection{Recommendations}

Based on its various findings, this study recommends the mandatory adoption of integrated reporting by the Financial Reporting Council of Nigeria (FRCN), the country's standard setter, as it is currently done in South Africa. Similarly, it is also recommended that the Companies and Allied Matters Act (as amended), 2004, LFN, which also defines the components of corporate reports, should be amended to allow for the mandatory inclusion of both financial and nonfinancial information in corporate reports. It is further recommended that the FRCN should liaise with the International Accounting Standards Board (IASB) to amend the subsisting Conceptual Framework to allow for the mandatory disclosure, in corporate reports, of non-financial information, like the contributions of intangible assets to value creation and the recognition of negative externalities of productive activities on the environment as well measures put in place to remedy them. The former Statements of Accounting Standards (SAS) 14 and 17 issued by the defunct Nigerian Accounting Standards Board (now FRCN), sought to address these issues of negative externalities of productive activities in the extractive industry in Nigeria. Since there are no equivalent IFRSs for them, it is recommended that they be reviewed and re-issued as IFRSs to cover all sectors with stringent provisions.

\section{References}

Adegbie, F.F., Akintoye, I.R., \& Olusanjo, O.R. (2019). Effect of integrated reporting practices on corporate disclosure and transparency in Nigerian quoted manufacturing companies. EPRA International Journal of Economic and Business Review, 7(6).

Adhariani, D. \& de Villiers, C. (2018). Integrated reporting: perspectives of corporate report preparers and other stakeholders. Sustainability Accounting, Management and Policy Journal, October. https://doi.org/10.1108/SAMPJ-02-2018-0043

Akintoye, I.R. (2016). Investment in the 21st Century. $3^{\text {rd }}$ edition. Lagos: Unique Educational Publishers.

Akintoye, I.R. (2019). Accounting: a mismanaged concept requiring urgent redefinition. Being the $28^{\text {th }}$ Inaugural Professorial lecture at the Babcock University, Ilisan on April 4.

Alucha, M., Hussain, N., \& Roszkowska-Mendes, M. (2019). Integrated reporting narratives: the case of an industry leader. Sustainability, 11, 976. Doi: 10.3390/su11040976

Appiagyei, K., Djajadikerta, H., \& Xiang, E. (2016). Integrated reporting and firm performance: a research framework. Proceedings of ECU Business Doctoral and Emerging Scholars Colloquium_2016_AHE, 123-129.

Asein, A. A., Soetan, T.A., \& Akintoye, I.R. (2019). Integrated reporting: meeting Nigeria stakeholders' information needs beyond financial performance. International Journal of Latest Engineering and Management Research, 4(2):94-108.

Association of National Accountants of Nigeria (2018). Audited Annual Report. Lagos: ANAN

Ayoola, T.J. \& Olasanmi, O. (2013). Business case for integrated reporting in the Nigerian oil and gas sector. Issues in Social and Environmental Accounting, 7(1), 30-54.

Baboukardos, D., \& Rimmel, G. (2016). Value relevance of accounting information under an integrated reporting approach: A research note. Journal of Accounting and Public Policy. In press. http://dx.doi.10.1016/j.jaccpubpol.2016.04.004

Bernardi, C. \& Stark, A.W. (2015). Environmental, social and governance disclosure, integrated reporting and the accuracy of analysts' forecasts, Working Paper, University of Manchester.

Beyer, A., Cohen, D., Lys, T., \& Walther, B. (2010). The financial reporting environment: review of the recent literature. Journal of Accounting and Economics, 50, 296-343.

Bhasin, M.L. (2017). Integrating corporate governance and forensic accounting: a study of an Asian country. International Journal of Management Sciences and Business Research, 6(1), 31-52.

Bhasin, M.L. (2017a). Integrated reporting at the crossroads: will it become trendsetter model for the corporate reporting. International Journal of Management Sciences and Business Research, 6(2), 35-59. February.

Bhasin, M.L. (2017b). Integrated reporting: the future of corporate reporting. International Journal of Management and Social Sciences Research, 6(2), 17-31. February,

Burgman, R. \& Roos, G. (2006). The information needs of internal and external stakeholders and how to respond: reporting on operations and intellectual capital. EIASM $2^{\text {nd }}$ Workshop on Visualising, Measuring and Managing Intangibles and Intellectual Capital, Maastricht, The Netherlands, October 25-27. 
Busco, C., Frigo, M. L., Quattrone, P., \& Riccaboni, A. (2013a). Integrated reporting: concepts and cases that redefine corporate accountability. Switzerland: Springer.

Busco, C., Frigo, M. L., Quattrone, P., \& Riccaboni, A. (2013b). Redefining corporate accountability through integrated reporting: what happens when values and value creation meet? Strategic Finance, 95(2), 33-41.

Busco, C., Frigo, M. L., Quattrone, P., \& Riccaboni, A. (2014). Leading practices in integrated reporting, management accountants will guide their companies on the journey to value creation. Strategic Finance, 23-32. September.

Camilleri, M.A. (2018). Theoretical insights on integrated reporting: the inclusion of non-financial capitals in corporate disclosures. Corporate communications: an International Journal, https://doi.org/10.1108/CCIJ-01-2018-0016 Companies and Allied Matters Act, LFN 2004.

Demirel, B. \& Erol, I. (2016). Investigation of integrated reporting as a new approach of corporate reporting. International Journal of Business and Social Research, 06(10).

Donaldson, T. \& Preston, L.E. (1995). The stakeholder theory of the corporation: concepts, evidence, and implications. Academy of Management Review, 20(1), 65-91

Dumay, J., Bernardi, C., Guthrie, J., \& La Torre, M. (2017). Barriers to implementing integrated reporting: an contemporary academic perspective. Being submission to the International Integrated Reporting Council's request for feedback from all stakeholders with knowledge of the International <IR>Framework, and specifically the enablers, incentives and barriers to its implementation (IIRC, 2017).

Eccles, R. G. \& Krzus, M. (2010). Integrated reporting for a sustainable strategy. Financial Executive, March, 29-32.

Enahoro, J.A. (2009). Design and bases of environmental accounting in oil and gas and manufacturing sectors in Nigeria. Being thesis submitted to the Department of Accounting, College of Business and Social Sciences, Covenant University, Ota, Nigeria.

Enderlie, G. (2004). The ethics of financial reporting. In G. Brenkert (ed.), Corporate Integrity and Accountability, 8799. London: Sage Publication

European Commission (2017). Non-financial reporting directive-transposition status. Retrieved from https://ec.europa.eu/info/publications/non-financial-reporting-directive-transposition-status_en

Farneti, F., Casonato, F., Montecalvo, M., \& De Villiers, C. (2019). The influence of integrated reporting and stakeholder information needs on the disclosure of social information in a state-owned enterprise. Meditari Accountancy Research forthcoming.

Financial Reporting Council of Nigeria (2019). National Code of Corporate Governance. Lagos: FGN Press

Financial Reporting Council of Nigeria (FRCN) Act no. 6, 2011

Flower, J. (2015). The International Integrated Reporting Council: a story of failure. Critical perspectives on accounting, 27, 1-17. http://dx.doi.org/10.1016/j.cpa.2014.07.002

Freeman, R. \& Evan, W. (1990). Corporate governance: a stakeholder interpretation. Journal of Behavioural Economics, 19(4), 337-360.

Freeman, R. (1994). The politics of stakeholder theory: some future directions. Business Ethics Quarterly,4(4), 409-421

Frias-Aceituno, J.V., Rodriguez-Ariza, L., \& Garcia-Sanchez, I.M. (2014). Explanatory factors of integrated sustainability and financial reporting. Business Strategy and the Environment, 23, 56-72.

Friedman, M. (1962). Capitalism and freedom. Chicago: The University of Chicago Press

Ghosh, S. (2019). Integrated Reporting in India: Research findings and insights. Chapter 18 in S.O. Idowu \& M. Del Baldo (ed.), Integrated Reporting, CSR, Sustainability, Ethics and Governance. 365-386. Springer Nature Switzerland.

Gokten, S. \& Gokten, P.O. (2017). Value creation reporting: answering the question, "value to whom" according to the International Integrated Reporting Framework. Zeszyty Teoretyczne Rachunkowosci, tom 91(147), s.145-169

Gray, R., Kouhy, R., \& Lavers, S. (1995). Corporate social and environmental reporting: a review of the literature and a longitudinal study of UK disclosure. Accounting, Auditing and Accountability Journal, 8(2), 47-77.

Haji, A.A., \& Anifowose, M. (2016). The trend of integrated reporting practice in South Africa: ceremonial or substantive? Sustainability Accounting, Management and Policy Journal, 7(2).

Higgins, C., Stubbs, W., \& Love, T. (2014). Walking the talk(s): organisational narratives of integrated reporting. Accounting, Auditing and Accountability Journal, 27(7), 1090-1119

Hurghis, R. (2017). Integrated reporting and board features. Audit Financial, XV (1-145), 83-92. https://doi.org/http://dx.doi.org/10.20869/AUDTF/2017/145/83

IASB (2018). IASB publishes revised Conceptual Framework. March 29. Retrieved from https://www.iasplus.com/en/news/2018/03/cf.

IFRS Foundation (2018). Conceptual framework for financial reporting-IFRS conceptual framework project summary. March.

IIRC (2013). The International $\langle I R>$ Framework. London: The International Integrated Reporting Council. 
Institute of Chartered Accountants of Nigeria-ICAN (2018). Annual report and audited financial statements. Lagos: ICAN

Institute of Directors, Southern Africa (2009). King III: Code of governance for South Africa. Retrieved from: http://www.iodsa.co.za/?kingIII

Ioana, D. \& Tiron-Tudor, A. (2014). New corporate reporting trends, analysis on the evolution of integrated reporting, 1221-1228.

Ioana, D. \& Tiron-Tudor, A. (2014). Research agenda on integrated reporting: new emergent theory and practice. Procedia Economics and Finance, 15, 221-227.

Ioannou, I., \& Serafeim, G. (2014). The consequences of mandatory corporate sustainability reporting: evidence from four countries. Harvard Business School Research Working Paper, (11-100).

Jaffar, N., Nor, A.S.M., \& Selamat, Z. (2018). Analysis of voluntary disclosure before and after the establishment of the integrated reporting framework. Accounting and Finance Review, 3(4), 105-113.

Johal, P. (2018). Corporate Reporting: from numbers to narrative. In E. Conway, E. and D. Byrne (Eds.). Contemporary Issues in Accounting. Chapter 6

Juma, B., Tumwebaze, Z., \& Orobia, L. (2019). The adoption of integrated reporting: a developing country perspective. Journal of Financial Reporting and Accounting, 17(1), 2-23

Kilic, M. \& Kuzey, C. (2018). Assessing current company reports to the IIRC integrated reporting framework. Meditari Accountancy Research, 26 (2), 305-333.

Liu, Z., Jubb, C., \& Abhayawansa, S. (2018). Analysing and evaluating integrated reporting: insights from applying a normative benchmark. Journal of Intellectual Capital, https://doi.org/10.1108/JIC-02-2018-0031

Loprevite, S., Ricca, B., \& Rupo, D. (2018). Performance sustainability and integrated reporting: empirical evidence from mandatory and voluntary adoption contexts. Sustainability, 10, 1351.

Matuszyk, I. \& Rymkiewicz, B. (2018). Integrated Reporting as a tool for communicating with stakeholdersadvantages and disadvantages. E3S Web of Conference, 35, 06004. https://doi.org/10.1051/e3sconf/20183506004

Moolman, J., Oberholzer, M., \& Steyn, M. (2016). The effect of integrated reporting on integrated thinking between risk, opportunity and strategy and disclosure of risks and opportunities. Southern African Business Review, 20, 600-627.

Nakib, M. \& Dey, P.K. (2018). The journey towards integrated reporting in Bangladesh. Asian Economic and Financial Review, 8(7), 894-913

Naynar, N.R., Ram, A.J., \& Maroun, W. (2018). Expectation gap between preparers and stakeholders in integrated reporting. Meditari Accountancy Research, https://doi.org/10.1108MEDAR-12-2017-0249

Nigerian Accounting Standards Board (2010). Report of the Committee on Road Map to the Adoption of IFRS in Nigeria. Lagos: Federal Government Press.

Nigerian Stock Exchange (2015) Rule book. www.nse.com.ng

Nurkumalasari, I.S., Restuningdiah, N., \& Sidharta, E.A. (2019). Integrated reporting disclosure and its impact on firm value: evidence in Asia. International Journal of Business, Economics and Law, 18(5), Feb. IISN 2289-1552

Okafor, T.G., Onyali, C.I. \& Onodi, B.E. (2016). Striking a balance between stakeholders' information needs and companies' sustainable development reports: an overview of selected African countries. Research Journal of Finance and Accounting, 7(5), 24-35.

Oliveira, J., Rodrigues, L.L., \& Craig, R. (2011). Voluntary risk reporting to enhance institutional and organizational legitimacy, evidence from Portuguese banks. Journal of Finance Regulatory Compliance.

Orshi, T.S., Dandago, K. I., \& Isa, R. (2019). Do boards determine integrated reporting in Nigerian listed oil and gas firms? SEISENSE Journal of Management, 2(4), 35-50. DOI: https://doi.org/10.33215/sjom.v2i4.157.

Pandey, I.M. (2004). Financial Management. 9th edition, Vikas Publishing House, PVT Ltd, New Delhi, India.

Roman, A. G., Mocanu, M., \& Hoinaru, R. (2019). Disclosure style and its determinants in integrated reports. Sustainability, 11, 1960.

Schwab, K. (1971). Modern enterprise management in Mechanical Engineering. Frankfurt/Main-Niederrad: VDMA

Serafeim, G. (2014). Integrated reporting and investor clientele. Working Paper, 14-069. April 4.

Setia, N, Abhayawansa, S., Joshi, M., \& Huynh, A.V. (2015). Integrated reporting in South Africa: some initial evidence. Sustainability Accounting, Management and Policy Journal, 6(3), 397-424.

Steyn, M. (2014). Organisational benefits and implementation challenges of mandatory integrated reporting: perspectives of senior executives at South African listed companies. Sustainability Accounting, Management and Policy Journal, 5(4), 476-503.

Stubbs, W., Higgins, C., \& Milne, M. (2016). An exploration of the information needs of selected stakeholders of integrated reporting. CPA Australia 
Sukhari, A. \& De Villiers (2018). The influence of integrated reporting on business model and strategy disclosures. Australian Accounting Review, forthcoming

Tweedie, D., Nielsen, C. \& Martinov-Bennie, N. (2018). The business model in integrated reporting: evaluating concept and application. Australian Accounting Review, 86(28), 3. Doi: 10.1111/auar.12196

Uddin, A. Md \& Safiuddin, Md (2015). Narrative reporting disclosures: a study of selected companies listed in Dhaka Stock Exchange (DSE). The Cost and Management, 43(5), 41-50. September-October. ISSN 1817-5090.

Ullah, M. \& Rahman, M.A. (2015). Corporate social responsibility reporting practices in banking companies in Bangladesh: impact of regulatory change. Journal of Financial Reporting and Accounting, 13(2), 200-225.

\section{APPENDIX 1}

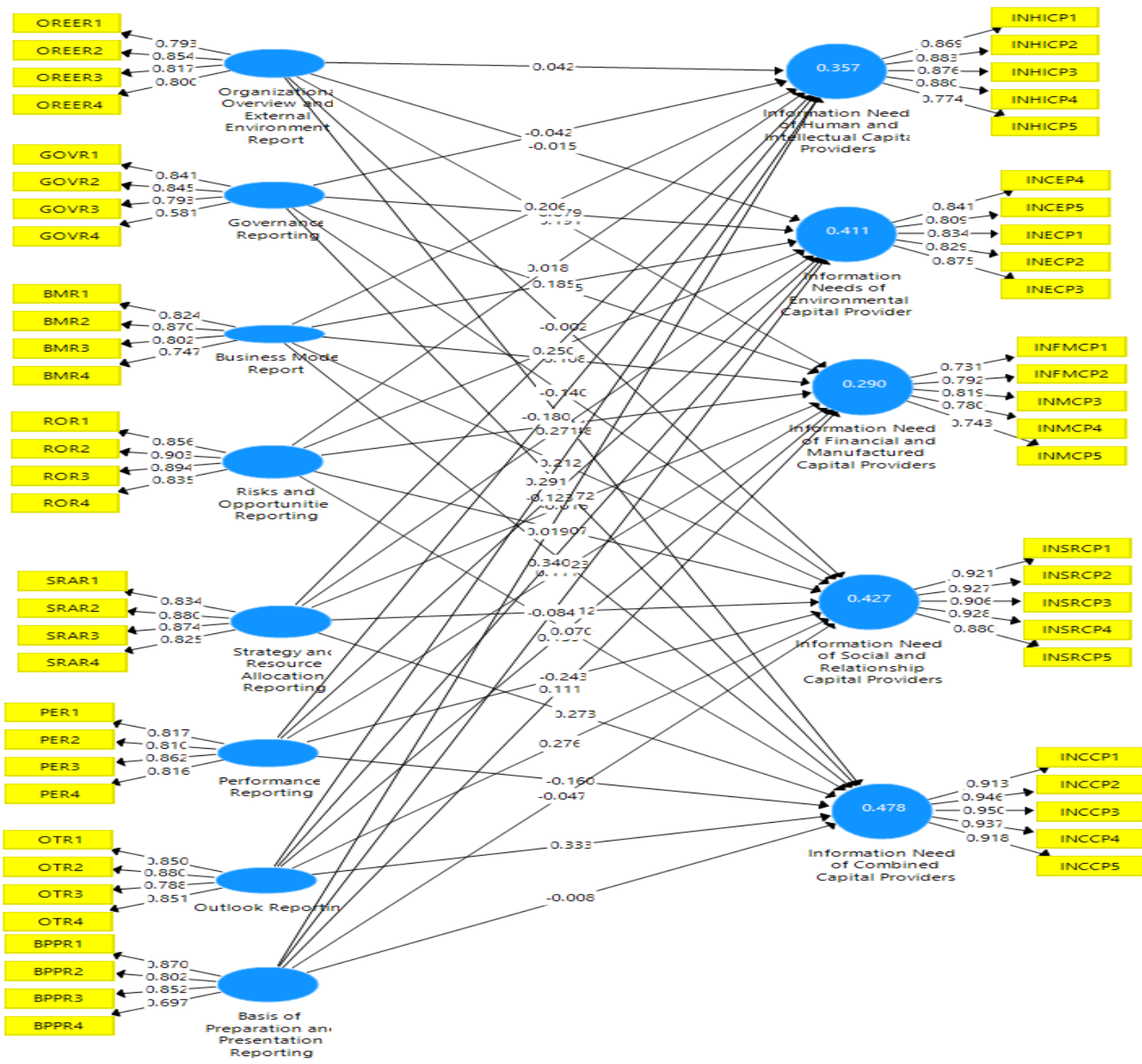

\section{APPENDIX 2}

Figure A: Structural Equation Model Critical Path for the Outer Loadings 


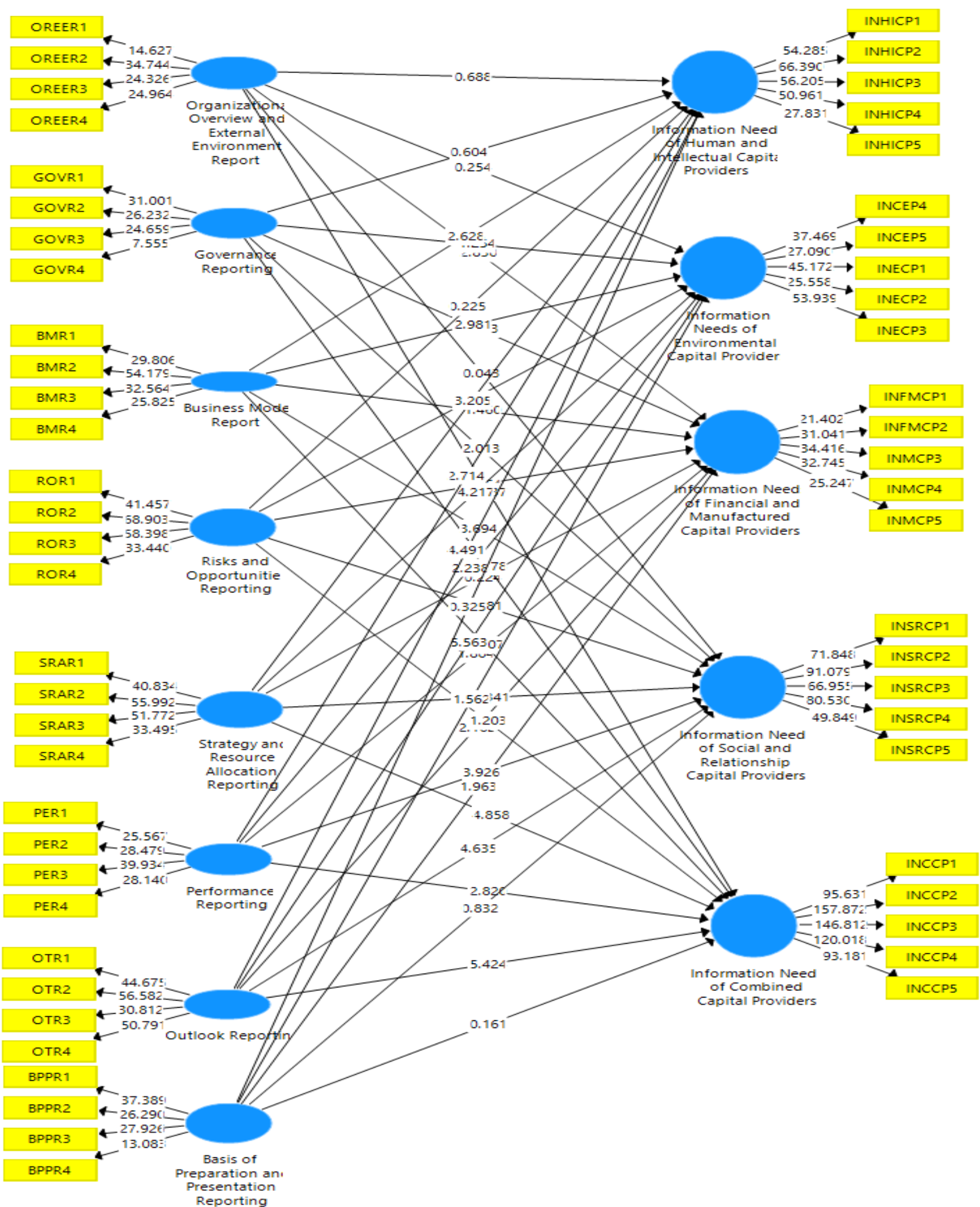

Figure B: Structural Equation Model Critical Path for the Level of Significance. 


\section{APPENDIX 3}

Table 6.Summary of Findings on Content Elements that Influence Information Needs of Stakeholders of Quoted Nigerian Companies

\begin{tabular}{|c|c|c|c|c|c|c|}
\hline $\mathbf{S} / \mathbf{N}$ & $\begin{array}{l}\text { CONTENT } \\
\text { ELEMENT }\end{array}$ & TYPE OF CAPITAL & RELATIONSHIP & $\begin{array}{l}\text { Adjusted } \\
\mathbf{R}^{2}\end{array}$ & F-Statistics & DECISION \\
\hline \multirow[t]{3}{*}{1} & $\begin{array}{l}\text { BPPR; BMR, GovR, } \\
\text { OREER, OTR, PER } \\
\text { and ROR }\end{array}$ & $\begin{array}{l}\text { Financial and } \\
\text { Manufactured }\end{array}$ & Positive & \multirow[t]{3}{*}{0.275} & \multirow[t]{3}{*}{$\begin{array}{l}15.815 \\
\text { statistically is } \\
\text { significant with p } \\
<0.05\end{array}$} & \multirow[t]{3}{*}{$\begin{array}{l}\text { ACCEPT } \\
\text { ALTERNATIVE } \\
\text { HYPOTHESIS }\end{array}$} \\
\hline & BPPR, OREER OTR & $\begin{array}{l}\text { Financial \& } \\
\text { Manufactured }\end{array}$ & Positive \& Significant & & & \\
\hline & SRAR & Financial \& Man. & NEGATIVE & & & \\
\hline \multirow[t]{3}{*}{2} & $\begin{array}{l}\text { BMR, OREER, OTR, } \\
\text { ROR and SRAR }\end{array}$ & Human and Intellectual & Positive & \multirow[t]{3}{*}{0.343} & \multirow[t]{3}{*}{$\begin{array}{l}21.495 \\
\text { statistically is } \\
\text { significant with p } \\
<0.05\end{array}$} & \multirow[t]{3}{*}{$\begin{array}{l}\text { ACCEPT } \\
\text { ALTERNATIVE } \\
\text { HYPOTHESIS }\end{array}$} \\
\hline & $\begin{array}{l}\text { BMR, OTR,PER and } \\
\text { SRAR }\end{array}$ & Human and Intellectual & Positive \& Significant & & & \\
\hline & GovR \& PER & Human \& Intellectual & NEGATIVE & & & \\
\hline \multirow[t]{3}{*}{3} & $\begin{array}{l}\text { BMR, OTR, ROR and } \\
\text { SRAR }\end{array}$ & Environmental & Positive & \multirow[t]{3}{*}{0.398} & \multirow{3}{*}{$\begin{array}{l}27.015 \quad \text { is } \\
\text { statistically } \\
\text { significant with p } \\
<0.05\end{array}$} & \multirow[t]{3}{*}{$\begin{array}{l}\text { ACCEPT } \\
\text { ALTERNATIVE } \\
\text { HYPOTHESIS }\end{array}$} \\
\hline & $\begin{array}{l}\text { BMR, OTR, PER and } \\
\text { SRAR }\end{array}$ & Environmental & Positive \& Significant & & & \\
\hline & $\begin{array}{l}\text { BPPR, GovR, OREER } \\
\text { \& PER }\end{array}$ & ENVIRONMENTAL & NEGATIVE & & & \\
\hline \multirow[t]{3}{*}{4} & $\begin{array}{l}\text { BMR, OTR, ROR and } \\
\text { SRAR }\end{array}$ & Social and Relationship & Positive & \multirow[t]{3}{*}{0.414} & \multirow{3}{*}{$\begin{array}{l}28.850 \quad \text { is } \\
\text { statistically } \\
\text { significant with p } \\
<0.05\end{array}$} & \multirow[t]{3}{*}{$\begin{array}{l}\text { ACCEPT } \\
\text { ALTERNATIVE } \\
\text { HYPOTHESIS }\end{array}$} \\
\hline & $\begin{array}{l}\text { BMR, GovR, OTR, } \\
\text { PER and SRAR }\end{array}$ & Social and Relationship & $\begin{array}{l}\text { Positive and } \\
\text { Significant }\end{array}$ & & & \\
\hline & $\begin{array}{l}\text { BPPR, GovR, OREER, } \\
\text { PER }\end{array}$ & Social \& Relationship & NEGATIVE & & & \\
\hline \multirow[t]{3}{*}{5} & $\begin{array}{l}\text { BMR, OREER, OTR, } \\
\text { ROR and SRAR }\end{array}$ & Combined & Positive & \multirow[t]{3}{*}{0.467} & \multirow[t]{3}{*}{$\begin{array}{l}35.451 \text { is } \\
\text { statistically } \\
\text { significant with } p \\
<0.05\end{array}$} & \multirow[t]{3}{*}{$\begin{array}{l}\text { ACCEPT } \\
\text { ALTERNATIVE } \\
\text { HYPOTHESIS }\end{array}$} \\
\hline & $\begin{array}{l}\text { BMR,OTR, PER and } \\
\text { SRAR }\end{array}$ & Combined & $\begin{array}{l}\text { Positive and } \\
\text { Significant } \\
\end{array}$ & & & \\
\hline & BPPR, GovR \& PER & COMBINED & NEGATIVE & & & \\
\hline
\end{tabular}

KEY: Basis of Preparation and Presentation Reporting (BPPR); Business Model Reporting (BMR); Governance Reporting (GovR); Organisational Overview and External Environment Reporting(OREER); Outlook Reporting(OTR); Performance Reporting(PER); and Risk and Opportunities Reporting(ROR); and Strategy and Resource Allocation Reporting (SRAR). 